\title{
Implementasi Pembelajaran K13 Terhadap Prestasi Belajar Siswa Kelas X IPS Mata Pelajaran Ekonomi Di SMAN 1 Ende
}

\author{
Florentina Kori, Sayful Amrin, Stefanus H.G Ma \\ e-mail: jakaamrin799@gmail.com,ephentino@gmail.com \\ Program Studi Pendidikan Ekonomi, FKIP, Universitas Flores
}

\begin{abstract}
ABSTRAK: Penelitian ini bertujuan untuk mengetahui (1) Implementasi K13 di Sman 1 Ende Tahun Pelajaran 2016/2017. (2) Prestasi Belajar Siswa Kelas X IPS Mata Pelajaran Ekonomi di Sman 1 Ende Tahun Pelajaran 2016/2017. Penelitian ini menggunakan pendekatan Deskriptif kualitatif. Instrumen utama penelitian adalah peneliti sendiri, data dilakukan dengan teknik (1) wawancara, (2) observasi (3) dokumentasi. Teknik analisis data menggunakan interaktif model Miles dan Huberman..Hasil penelitian menunjukan (1) Implementasi pembelajaran K13 sudah baik diterapakan. (2) Prestasi belajar siswa setelah diimplementasikan pembelajaran K13 dibuktikan melalui proses belajar mengajar yang berlangung di kelas, semangat siswa sangat tinggi mencari tahu apa yang mereka belum tahu. Pembelajaran K13 siswa lebih banyak berperan aktif dalam kelas, mereka lebih suka bertanya dan berdiskusi. Kesimpulan dan saran (1) Kepada guru mata pelajaran IPS Ekonomi untuk terus berusaha dalam peningkatan pemahaman tentang pembelajaran K13 kepada siswa; (2) kepada peserta didik sebagai objek dalam pembelajaran K13 agar lebih aktif keikutsertaan dalam kegiatan pembelajaran di kelas sehingga dapat meningkatkan prestasi belajar.
\end{abstract}

Kata kunci : implementasi K13, prestasi belajar.

ABSTRACT: The aim of this research are to know (1) the implementation of K13 at SMA Negeri 1 Ende in academic year 2016/2017. (2) students achievement of class $X$ of social science department on economics subject at SMA Negeri 1 Ende in academic year 2016/2017 This research used descriptive qualitative approach. The main instrument of this research was researcher ownself. Interview, observation and documentation were the method used for gathering data. Meanwhile, interactive models of Miles and Huberman used for data analysis. he result shows that (1) the implementation of K13 already applied properly. (2) after K13 implemented during teaching and learning process, the achievement of students can be seen through the spirit of the students to find out what they do not know yet are high. Beside that, the students are also active participate in classroom, and they tend to ask and discuss more. The conclusion and suggestion addressed to; first is to the teacher who handle social science economic subject is expected to keep trying on increasing students understanding about K13; second is to the students as the object where K13 implemented are expected to be more active and participate in classroom activities so that their achievement can be increased.

Keywords: implementation K13, learning achievement.

\section{PENDAHULUAN}

Pendidikan adalah usaha sadar dan terencana untuk mewujudkan suasana belajar dan proses pembelajaran agar peserta didik secara aktif mengembangkan potensi dirinya untuk memiliki kekuatan spiritual keagamaan, pengendalian diri, kepribadian, kecerdasan, akhlak mulia, serta ketrampilan yang diperlukan dirinya, masyarakat, bangsa dan negara (UU No.20 
Tahun 2003 tentang Sisdiknas, pasal 1: ayat 1$)$.

Pendidikan Nasional yang berdasarkan Pancasila dan UndangUndang Dasar Negara Republik Indonesia Tahun 1945 berfungsi mengembangkan kemampuan dan membentuk watak serta peradaban bangsa yang bermartabat dalam rangka mencerdaskan kehidupan bangsa, bertujuan untuk mengembangkan potensi peserta didik agar menjadi manusia yang beriman dan bertakwa kepada Tuhan Yang Maha Esa, berakhlak mulia, sehat, berilmu, cakap, kreatif, mandiri, dan menjadi warga negara yang demokratis serta bertanggung jawab

Kurikulum 2013 diterapkan dengan menelaah Standar Kompetensi Lulusan (SKL), Kompetensi Inti (KI), dan Kompetensi Dasar (KD) secara benar. Jadi guru perlu memetahkan setiap KD terhadap KI dan SKL yang bersesuaian. Ketika hendak mengajar, perlu diperhatikan apa yang harus dicapai oleh siswa. Kegiatan belajar harus diarahkan untuk membentuk siswa menjadi manusia yang beriman dan bertaqwa kepada Tuhan Yang Maha Esa, berakhlak mulia, sehat, berilmu, cakap, kreatif, mandiri, dan menjadi warga negara yang demokratis serta bertanggung jawab sesuai tujuan Pendidikan Nasional (pasal 3 UU No. 20 Tahun 2003 tentang Sistem Pendidikan Nasional).

Dalam implementasi kurikulum 2013, guru dan kepala sekolah merupakan dua elemen penting dalam kesusksesan implementasi Kurikulum 2013, yang harus memperhatikan tiga hal penting dalam pengembangan Kurikulum 2013 yang berbasis kompetensi, yaitu: (1) penetapan kompetensi yang akan dicapai; (2) pengembangan strategi untuk mencapai kompetensi; dan (3) evaluasi. Kompetensi yang ingin dicapai merupakan pernyataan tujuan (goal statement) yang hendak diperoleh peserta didik dan menggambarkan hasil belajar (learning outcomes) pada aspek pengetahuan, keterampilan, nilai dan sikap. Strategi mencapai kompetensi adalah upaya untuk membantu peserta didik dalam menguasai kompetensi yang ditetapkan, misalnya: membaca, menulis, mendengarkan, berkreasi dan mengobservasi, sampai terbentuk suatu kompetensi. Sedangkan evaluasi merupakan kegiatan penilaian terhadap pencapaian kompetensi bagi peserta didik. (Mulyasa, 2013: 69-70).

Hasil pengamatan yang di SMA Negeri 1 Ende, ditemukan berbagai permasalahan ketika jam pelajaran ekonomi berlangsung antara lain:(1) Pada umumnya sekolah relatif belum sepenuhnya menerapakan Kurikulum 2013;(2)Guru-guru belum menerapkan metode pembelajaran kurikulum 2013 secara inovatif: (3) Proses belajar mengajar yang berlangsung sebagian besar masih banyak ceramah dan didominasi guru; (4) Sebagian guru belum menunjukkan kreativitasnya dalam proses pembelajaran; (5) Penilaian yang dilakukan guru masih menekankan pada aspek kognitif saja belum penilaian otentik.

\section{LANDASAN TEORI \\ Pembelajaran}

Kamus Besar Bahasa Indonesia (2007:17) mendefenisikan kata pembelajaran berasal dari kata ajar yang berarti petunjuk yang diberikan kepada orang supaya diketahui atau diturut, sedangkan pembelajaran berarti proses, cara, perbuatan menjadikan orang atau makluk hidup belajar. Istilah Pembelajaran merupakan istilah baru yang digunakan untuk menunjukkan kegiatan guru dan peserta didik, menggantikan istilah sebelumnya yaitu" Proses Belajar Mengajar" dan " pengajaran".

$$
\text { Ciri-ciri Pembelajaran: }
$$

Meningkatkan dan mendukung proses belajar peserta didik. (2) Adanya interaksi atau hubungan timbal balik. 3) Adanya komponen-komponen yang saling berkaitan satu sama lain.

Kurikulum 13 
Pembelajaran K13 adalah sebuah kurikulum yang mengutamakan pemahaman, skill, dan pendidikan berkarakter, siswa dituntut untuk paham atas materi, aktif dalam berdiskusi dan presentasi serta memiliki sopan santun disiplin yang tinggi. Dalam pembelajaran K13 juga dikenal ada 14 prinsip utama adalah sebagai berikut: (1) dari siswa diberitahu menuju siswa mencari tahu.(2) dari guru sebagai satu-satunya sumber belajar menjadi belajar berbasis aneka sumber (3) dari pendekatan tekstual menuju proses sebagai penguatan penggunaan pendekatan ilmiah (4) dari pembelajaran berbasis konten menuju pembelajaran berbasis kompetensi (5) dari pembelajaran persial menuju pembelajaran terpadu (6) dari pembelajaran yang menekankan jawaban tunggal menuju pembelajaran dengan jawaban yang kebenarannya multi dimensi (7) dari pembelajaran verbalisme menuju keterampilan aplikatif (8).Pembelajaran yang mengutamakan pembudayaan dan pemberdayaan siswa sebagai pembelajar sepanjang hayat

Prestasi Belajar

Prestasi belajar adalah bukti keberhasilan yang telah dicapai oleh seseorang. Dengan demikian, prestasi belajar merupakan hasil maksimum yang bisa oleh seseorang setelah melaksanakan usaha-usaha belajar. (Winkel, 1996:226). faktor-faktor yang mempengaruhi prestasi belajar: (1) Faktor intern: Kecerdasan, bakat, minat dan motivasi, (2) Faktor eksteren: Keluarga dan sekolah.

\section{METODE PENELTIAN}

Jenis Penelitian

Jenis penelitian yang dipakai dalam penelitian ini adalah peneliti deskriptif kualitatif

Teknik Pengumpulan Data

Pengumpulan data menggunakan ;

1.Wawancara

2.Observasi

3.Dokumentasi

Analisa Data
Tehnik analisa data menggunakan Miles dan Huberman yang mengatakan bahwa ada tiga langkah data kualitatif yaitu: reduksi data, penyajian data dan verivikasi/kesimpulan, setelah melakukan analisa data, langkah selanjutnya melakukan pengecekan keabsaahan data, Agar data yang diperoleh dalam penelitian ini dapat dijamin kepercayaan, maka pengecekan kredibilitas data ditempuh dengan cara sebagai berikut: a). Triagulasi b) Pengecekan anggota,c). Diskusi sejawat

\section{PEMBAHASAN \\ Implementasi Pembelajaran K13}

Kurikulum 2013 secara umum sering diartikan sebuah kurikulum yang mengutamakan pemahaman skill, dan pendidikan berkarakter. siswa dituntut untuk paham atas materi, aktif dalam berdiskusi dan presentasi serta memiliki sopan santun disiplin yang tinggi. Tujuan penyusunan kurikulum 2013 adalah mempersiapkan insan Indonesia untuk memiliki kemampuan hidup sebagai pribadi dan warga negara yang produktif, kreatif, inovatif dan afektif serta mampu berkontribusi pada kehidupan bermasyarakat, bernegara, dan peradaban dunia. temuan peneliti di Sman 1 Ende tentang implementasi pembelajaran K13 pada siswa kelas $\mathrm{X}$ adalah suatu pembelajaran yang lebih menekankan pada aspek sikap, keterampilan dan juga pengetahuan yang nantinya akan membentuk insan manusia yang lebih kreatif dalam melakukan sesuatu.

Hasil observasi yang dilakukan oleh peneliti selama melakukan penelitian di SMAN 1 Ende menunjukkan bahwa siswa memiliki minat belajar yang membanggakan dan memuaskan siswa di kelas $\mathrm{X}$ aktif dalam mengikuti proses belajar mengajar di kelas, siswa rajin bertanya dengan teman dan dengan gurunya, Berdasarkan paparan satuan data melalui hasil wawancara dan observasi hasil temuan penelitian yang telah dibahas 
menunjukkan bahwa prestasi belajar siswa kelas X setelah diterapakan pembelajaraan K13 prestasi belajar siswa jadi meningkat,.

Temuan penelitian dilapangan menjelaskan pembelajaran K13 merupakan sebuah Kurikulum baru yang sangat menyenangkan bagi siapa saja, termasuk siswa Sman I Ende, karena tidak semua materi dan pelajaran terpusat dari guru. Guru hanya memberikan dan menjelaskan sub pokok materi, kemudian siswa dibagi dalam beberapa kelompok untuk selanjutnya mendiskusikan materi tersebut dengan kelompoknya. Setelah selesai mendiskusikan baru dipresentasikan didepan kelas yang disaksikan oleh guru dan kelompok lainnya. Dengan menggunakan pembelajaran K13 dapat dikatakan bahwa siswa memiliki motivasi yang cukup tinggi dan antusias serta respon menanggapi pada saat proses belajar-mengajar berlangsung

\section{Prestasi Belajar Siswa Kelas X IPS}

Prestasi belajar secara umum dipandang sebagai perwujudan nilai- nilai yang diperoleh siswa melalui proses pembelajaran, prestasi belajar bisa menunjuhkan tingkat keberhasilan seseorang yang dicapai karena telah melaakukan usaha belajar yang optimal

Prestasi belajar siswa kelas $\mathrm{X}$ di SMAN 1 Ende setelah diterapkan pembelajaran k13 sangat meningkat karena mereka lebih aktif dalam pembelajaran di kelas, guru hanya memberikan sub pokok materi dan kelompok selanjutnya mereka akan mencari tahu sendiri materi yang diberikan dan jika peserta didik belum paham, biasanya langsung bertanya kepada guru.

Peningkatan bisa dilihat nilai Ujian semester ganjil dimana, banyak peserta didik yang memperoleh nilai di atas rata-rata, bahkan ada yang dapat nilai melebihi nilai rata-rata, dengan ini membuktikan pembelajaran K13 bisa diterima dan dimengerti serta menyenangkan bagi peserta didik, hal ini menurut mereka dikarenakan mereka dapat mencari tahu sendiri apa yang mereka belum tahu, hal ini juga terbukti dengan nilai-nilai yang mereka peroleh dalam ujian semester ganjil. Temuan penelitian ini berkorelasi dengan pengertian prestasi belajar siswa yang yang dikemukakan oleh Mulyasa yang menjelaskan hasil belajar merupakan hasil pengukuran dari penilaian usaha belajar yang dinyatakan dalam bentuk simbol, huruf, maupun kalimat yang menceritakan hasil yang sudah dicapai oleh setiap anak pada periode tertentu

\section{KESIMPULAN DAN SARAN Kesimpulan}

Implementasi pembelajaran K13 pada kelas X IPS di SMAN 1 Ende Berdasarkan temuan penelitian dapat dikelompokan menjadi dua yaitu: ada siswa yang berperan aktif dalam pembelajaran K13, yang dapat dilihat saat proses belajar mengajar berlangsung di kelas, mereka saling menyangga satu sama lain dalam diskusi kelompok dan ada siswa yang malas berperan aktif dalam kelompok yang dapat dilihat saat proses belajar mengajar berlangsung dalam kelas Pembelajaran K13 sangat baik diterapkan karena siswa lebih proaktif dalam kelas sehingga suasana belajar lebih terlihat dalam kelas dibandingkan dengan penerapan kurikulum sebelumnya.

\section{Saran}

Guru harus menciptakan komunikasi yang baik dengan siswa agar apa yang dilakukannya dapat berdampak positif untuk kemajuan belajarnya sehingga tercapainya prestasi belajar yang lebih memuaskan dan bagi lembaga diharapkan menyediakan media pembelajaran yang dirancang bagi siswa dan guru atau memakai yang sesuai dengan materi/kurikulum perkembangan zaman khususnya pada mata pelajaran Ekonomi. 


\section{Daftar Pustaka}

Djamarah, Syaiful Bahri. 1994. Prestasi Belajar dan Kompetensi Guru. Surabaya: Usaha Nasional.

Arikunto, Suharsimi. 2002. Prosedur Penelitian. Jakarta: PT Rineka Cipta.

Hamdani. 2011. Dasar-Dasar Kependidikan. Bandung: PT Pustaka Setia.

Milles dan Hubermen. 1994. Teknik Analisis Data. Jakarta:
Mulyasa, H. E. 2013. Pengembangan dan Implementasi Kurikulum 2013. Bandung: PT Remaja Rosdakarya.

Muhadjir. 2000. Teknik Analisis Data. Malang: Bandung: Psikologi Pendidikan. Bandung: Remaja Karya. Sanjaya,

Moleong. 2011. Metedologi Penelitian Kualitatif. Bandung: PT Remaja Rosdakarya. 